\title{
Strategies for increasing the terminal efficiency of an Educational Degree Program in a University
}

\section{Estrategias para el incremento de la eficiencia terminal de un Programa Educativo de Licenciatura en una Universidad}

GONZÁLEZ-TIRADO, Blanca Delia*†, OLACHEA-PARRA, Luis Fernando, LIMÓN-ULLOA, Roberto and RUIZ-SALAS, Nidia Carolina

Instituto Tecnológico de Sonora, Campus Empalme

ID $1^{\text {st }}$ Author: Blanca Delia, González-Tirado / ORC ID: 0000-0002-1712-5999

ID $1^{\text {st }}$ Coauthor: Luis Fernando, Olachea-Parra / ORC ID: 0000-0003-3667-363X

ID $2^{\text {nd }}$ Coauthor: Roberto, Limón-Ulloa / ORC ID: 0000-0001-8443-7426

ID $3^{\text {rd }}$ Coauthor: Nidia Carolina, Ruiz-Salas / ORC ID: 0000-0003-0812-1555

DOI: $10.35429 /$ EJRC.2019.9.5.1.5

Received July 20, 2019; Accepted December 15, 2019

\begin{abstract}
The design of strategies to increase the terminal efficiency of the Educational Program (EP) Bachelor of Administration of the Sonora Technological Institute (ITSON) Empalme Campus, in order to contribute to compliance with the indicators of the external accrediting body Council of Accreditation in Sciences Administrative, Accounting and Related (BAAARS), is the objective of this investigation. One of the main problems of this Bachelor, is the low terminal efficiency. To counteract this situation, it was decided to apply the methodology of Hernández (2011), who proposes four stages: set goals, define problems (gap) and define livelihoods, strategic ideas of modernization and their scenarios (awareness) and formulation of the strategy. The results obtained were differences of the data of the Comprehensive System of School Paths (SITE) of the ITSON with the data of the Educational Program (EP), a database was generated with specific information of the generational cohorts 20132017, 2014-2018 and 2015 - 2019, the relationship with the cultural, social services and school registration departments of the institution was strengthened, a report was made of the current situation of the students, the creation of an individual action plan, all of the above aimed to increase terminal efficiency.
\end{abstract}

\begin{abstract}
Resumen
El diseño de estrategias para el incremento de la eficiencia terminal del Programa Educativo (EP) Licenciado en Administración del Instituto Tecnológico de Sonora (ITSON) Campus Empalme, con la finalidad de contribuir al cumplimiento de los indicadores del organismo acreditador externo Consejo de Acreditación en Ciencias Administrativas, Contables y Afines (BAAARS), es el objetivo de esta investigación. Uno de los principales problemas de esta Licenciatura, es la baja eficiencia terminal. Para contrarrestar esta situación, se decidió aplicar la metodología de Hernández (2011), quien plantea cuatro etapas: fijar objetivos, definición de problemas (brecha) y definir sustento de cambio, ideas estratégicas de modernización y sus escenarios (sensibilización) y formulación de la estrategia. Los resultados obtenidos fueron diferencias de los datos del Sistema Integral de Trayectorias Escolares (SITE) del ITSON con los datos del Programa Educativo (EP), se generó una base de datos con información específica de las cohortes generacionales 2013- 2017, 2014 - 2018 y 2015 - 2019, se fortaleció la vinculación con los departamentos de cultural, servicios social y registro escolar de la institución, se llevó a cabo un reporte de la situación actual de los estudiantes, la creación de un plan de acción individual, todo lo anterior encaminado a elevar la eficiencia terminal.
\end{abstract}

Trayectoria académica, Egresado, Eficiencia Terminal

Academic career, Graduate, Terminal Efficiency, Accreditation

Citation: GONZÁLEZ-TIRADO, Blanca Delia, OLACHEA-PARRA, Luis Fernando, LIMÓN-ULLOA, Roberto and RUIZSALAS, Nidia Carolina. Strategies for increasing the terminal efficiency of an Educational Degree Program in a University. ECORFAN Journal- Republic of Cameroon. 2019, 5-9: 1-5

\footnotetext{
* Correspondence to Author (email: blanca.gonzalez@itson.edu.m)

$\uparrow$ Researcher contributing first author.
} 


\section{Introduction}

The Higher Education Institutions (HEI), in their desire to ensure the educational quality of excellence, submit their educational programs to accreditation processes in order to know the strengths and areas of opportunity. In the case of the Educational Program (EP) under study, the Board of Accreditation in Administrative, Accounting and Related Sciences (BAAARS), is the body to which it is subject to evaluation. For BAAARS (2018), obtaining educational accreditation is a hallmark that ensures the quality of educational programs. To obtain this valuable badge, the Higher Education Institution must meet quality standards in different areas such as; the Curriculum, Integral Training, Services for learning, Infrastructure and equipment, among others.

In this EP, within its process of continuous improvement, is the fulfillment of the recommendations issued by the accrediting body, which highlights the category of Students. Therefore, this research is focused on increasing the indexes of terminal efficiency through strategies that allow compliance with the indicators of the accrediting body.

\section{Justificaction}

Since terminal efficiency is one of the indexes that has the greatest impact on the productivity of an educational program, it is important to determine the causes that prevent graduates from carrying out their degree process. For this reason, having strategies that help increase the indexes of terminal efficiency will allow the EP to obtain benefits, among others; to comply with the indicators of the external accrediting body, to have graduates who through their university degree can quickly position themselves in the workplace, have a quality educational program with a good image and also the recognition of prospects to enter this race. The above will serve to replicate at the institutional level the strategies implemented in this EP and which, in turn, allow the university to increase the indexes of terminal efficiency in all its educational programs.

\section{Problem}

For HEI, it is very important to have graduates, since this allows them to improve the terminal efficiency indicators and at the same time counteract the lag and dropout; however, in the national context there is evidence that for every 10 young people who enter the university, only five manage to obtain the professional degree, that is, that the other half only graduated as an intern from the institution or defected in some semester of the degree (Hernández, 2015). In the Technological Institute of Sonora (ITSON), educational programs live closely this reality, specifically in the EP of Administration of the Empalme Campus is a latent problem among its graduates, since according to an analysis made in the last three corresponding generations to the cohorts 2013-2017, 2014-2018 and 2015-2019, approximately $30 \%$ of the students who entered were entitled. For all of the above, the following question arises, does carrying out a study of the academic causes for which the students do not graduate, will allow the Educational Program of Graduate in Administration, establish the relevant strategies to increase the terminal efficiency of their graduates?

\section{Hypothesis}

An Educational Program has better results in an accreditation process, when strategies are generated to comply with the indicators.

\section{Objective}

Design strategies to increase the terminal efficiency of the ITSON Empalme Bachelor of Education Education Program, in order to contribute to the compliance of the indicators of the external accrediting body BAAARS.

\section{Theoretical framework}

The school trajectory is defined as the path followed by a student or the group of students of the same cohort in a certain time since their entry, permanence and discharge; that is to say, it is the monitoring that an institution carries out of the transit of its students with respect to their school performance, approval, reprobation, with the purpose of implementing the necessary actions that reduce the lag and dropout and thereby, improve terminal efficiency ( ITSON, CDA, 2015). 
The generational cohort is the group of students who enroll in a career and remain in it until the end of their curriculum or abandonment (ITSON, CDA, 2015).

At graduation, students who covered the total subjects of their curriculum at the time it is observed are considered, even if they have not covered other degree requirements (ITSON, CDA, 2015).

For the SEP (2016), the graduate student is the student who is awarded a certificate of completion of studies, once an educational level is concluded. Meanwhile, in the description of the Graduate, the student is considered that, having approved all the subjects and established requirements of a study program during the immediate previous school year, the corresponding certificate of studies is granted (SEP, 2019).

Terminal efficiency is defined as the comparative relationship between the number of students who enroll for the first time in a professional career, starting from that moment in a certain generation (cohort) and who manage to graduate after having accredited all the subjects in the time stipulated by the study program (ITSON, CDA, 2015). The calculation of the terminal efficiency of a cohort of any educational level is used under the formula of the number of graduates of a cohort among the base number of the cohort (SEP, 2019).

The efficiency indicator is the number of students who graduate from a certain educational level in a school year, for every one hundred students of the initial cohort of the same level (SEP, 2019).

It is important to highlight that of the indicators that determine the way in which an educational system is operating, the terminal efficiency will undoubtedly be the first to reflect the state of things to talk about the quality of the teaching-learning process, plans and programs, Evaluations of both educational and diagnostic achievement of teachers, educational infrastructure, among others (SEP, 2019).
The terminal efficiency by cohort is represented by the cohort students who graduated in the maximum time established in their curriculum (SITE, ITSON, 2018). While the terminal efficiency to date, it is the students of the cohort who have graduated to the date of information extraction (SITE, ITSON, 2018).

The terminal efficiency by cohort at the first year, are the students of the cohort who graduated up to one year after the time indicated in their curriculum (SITE, ITSON, 2018). And the efficiency of qualification by cohort for the second year, is represented by the students of the cohort who graduated up to two years after the time indicated in their curriculum (SITE, ITSON, 2018).

Accreditation is a process through which a Higher Education Institution (HEI) submits its academic programs to an evaluation in order to obtain recognition by a recognized and endorsed non-governmental organization that its academic offer meets standards quality. Therefore, it constitutes a reliable source of credibility and trust (BAAARS, 2018).

Among the benefits granted by BAAARS are: access to institutional support programs that contribute to the integral improvement of its human capital, equipment and infrastructure; public recognition as a prestigious institution; exchange of best practices and expansion of institutional alliances and the satisfaction of demand and expectations of society with quality educational services. The accreditation process benefits; to the academic program, to the Institution, to students and teachers, to future employers and to education in Mexico (BAAARS, 2018).

\section{Research Methodology}

\section{Participants}

For the purposes of this research, the members of the last three generational cohorts, 2013-2017, 2014-2018 and 2015-2019, which comprise a total of 44 students, were considered participants. 


\section{Instruments}

Two institutional inputs were used to obtain and analyze the data; the platform of the Comprehensive System of School Paths (SITE), which includes the list of the students belonging to the generational cohorts, the history of the students referring to dropout rates, disapproval by course, losses, advancement of English, dropout and averages per course.

The second input consists of a sheet with data of the students of the generations under study, which includes ID, name, program, curriculum, cell phone number, email, average, real cohort cycle, apparent cohort cycle, date of admission to the cohort, discharge date, failure rate, degree date, degree option, last status in the curriculum, plan subjects, tuition due, indicator of school documents and library debit.

\section{Process}

In order to design the strategies, the methodology of Strategic Planning of Hernández (2011) was taken as a basis, which proposes four stages: setting objectives, defining problems (gap) and defining change support, strategic ideas of modernization and their scenarios (awareness) and strategy formulation.

\section{Results}

The implementation of the four stages of Hernández (2011), yielded significant results for the design of the strategies, as described below:

Stage 1. Set objectives. A diagnosis of the situation of the generational cohorts (20132017, 2014-2018 and 2015-2019) was carried out. The analysis allowed identifying the elements proposed by the SITE, as a first objective, making a comparison through a sheet with real data of the members of the cohorts of the EP of the ITSON Empalme LA, establishing strategies and raising the terminal efficiency index.
Stage 2. Definition of problems (gap) and define change support. Based on what was observed in the trajectories of the generational cohorts (2013-2017, 2014-2018 and 2015-2019), the need was found to have indispensable information for the real and objective study of the situation of the Graduate Educational Program in Administration, with respect to the school trajectory, specifically with regard to qualification in order to comply with raising the terminal efficiency index.

3. Strategic ideas of modernization and its scenarios (awareness). Once the problems or areas of opportunity were detected, the possible strategies were listed. one). Identification of the students that make up the three generational cohorts under study. two). Actual academic situation of each of the students that make up the three generational cohorts. 3). Evaluation of compliance with the requirements established in the ITSON titling regulations and 4). Report on the current and individual situation of the cohort members.

4. Strategy formulation. Regarding the identification of the students that make up the three generational cohorts under study, the strategy consisted of requesting information from the school registration area, which redirects to consult the platform of Comprehensive Systems of School Paths (SITE), in the which some differences with the data were detected as well as the need to have specific information of the students of the EP of the ITSON Empalme LA.

Regarding the real academic situation of each of the students that make up the three generational cohorts, it was found that the SITE did not provide data such as cultural hours, hours of social service, tuition fees, library collections, lack of school documents as well as the compliance status of university English subjects.

Representing the above, critical and indispensable information to identify which students are in the capacity of graduates, who meet the qualification requirements, and that impact on terminal efficiency is achieved. 
In the strategy that corresponds to the evaluation of the fulfillment of the requirements established in the ITSON titling regulations, the link between the Educational Program of Bachelor of Administration with the institutional departments was achieved; cultural, social service and school registration, which allowed obtaining information for a database that included these student indicators.

And, finally, the report of the current and individual situation of the members of the cohort, allowed the student to become aware and know their school situation to design in coordination with the EP of LA an action plan that allows him to strategically obtain his job title.

\section{Acknowledgments}

We thank the Sonora Institute of Technology, which, through the Program for the Promotion and Support of Research Projects (PROFAPI), financed the present research.

\section{Conclusions}

The increase in the terminal efficiency of the ITSON Empalme Administration Graduate Educational Program was the objective of this research, and was accomplished through the design of specific strategies, based on the particular context of this career. The foregoing arises as part of the accreditation process of this program, in 2016, by the BAAARS organization.

The initial database gives a parameter of the current school situation of the students, however, it requires adding a greater number of indicators to identify the academic, nonacademic, economic and even personal factors that affect the student's trajectory.

This study requires future research to help counteract the problems related to terminal efficiency, such as, low, dropouts, lag, disapproval, low school performance that negatively impact the accreditation of university educational programs.

The increase in the terminal efficiency indices will depend on the implementation of the strategies defined exprofeso for this research..

\section{References}

BAAARS. (2018). BAAARS. Recuperado el 2 de Julio de 2019, de BAAARS: www.caceca.org

Hernández, L. (7 de Enero de 2015). Excelsior. Obtenido de https://www.excelsior.com.mx/nacional/2015/0 1/07/1001285

Hernández, S. (2011). Introducción a la administración: Teoría general administrativa: origen, evolución y vanguardia (Pag. 287). México: The McGraw-Hill (Libro online). Recuperado de: https://datospdf.com/downloadFile/5a44dfc7b7 d7bc422b969689

ITSON, CDA. (Marzo de 2015). Evaluación Curricular de los Programas Educativos. Taller: "Análisis de los indicadores de la trayectoria escolar".

SEP. (2016). Secretaría de Educación Pública. Recuperado el 8 de Julio de 2019, de Secretaría de Educación Pública: http://planeacion.sec.gob.mx/upeo/GlosariosIni cio20162017/SUPERIOR2016.pdf

SEP. (2019). Secretaría de Educación Pública. Recuperado el 10 de Julio de 2019, de Secretaría de Educación Pública: https://www.planeacion.sep.gob.mx/Doc/estadi stica_e_indicadores/lineamientos_formulacion_ de_indicadores.pdf

SITE ITSON. (2018). SITE. Recuperado el 25 de Junio de 2019, de Sistema Integral de Trayectorias Escolares: https://trayapps.itson.edu.mx/SITE/ 